\title{
Electrical Load Forecasting Using Genetic Algorithm Based Holt- Winters Exponential Smoothing Method
}

\author{
(D) Yunus Emre ÖZGER ${ }^{1}$, (D) Mustafa AKPINAR², (D Zabit MUSAYEV³, (D)Mustafa YAZ ${ }^{4}$ \\ ${ }^{1}$ Corresponding Author; Bozok Üniversitesi, Mühendislik-Mimarlık Fakültesi, Elektrik-Elektronik Mühendisliği; \\ https://orcid.org/0000-0001-5292-2961; yunusozger66@gmail.com \\ ${ }^{2}$ Bilgisayar ve Bilişim Bilimleri Fakültesi, Yazılım Mühendisliği; https://orcid.org/0000-0003-4926-3779; \\ akpinar@sakarya.edu.tr \\ ${ }^{3}$ Bozok Üniversitesi, Mühendislik-Mimarlık Fakültesi, Elektrik-Elektronik Mühendisliği; \\ https://orcid.org/0000-0002-4813-6105; zabit.musayev@bozok.edu.tr \\ ${ }^{4}$ Bozok Üniversitesi, Mühendislik-Mimarlık Fakültesi, Elektrik-Elektronik Mühendisliği; \\ https://orcid.org/0000-0001-7042-7649; mustafa.yaz@bozok.edu.tr
}

Received 02 August 2019; Revised 13 August 2019; Accepted 28 August 2019; Published online 29 August 2019

\begin{abstract}
Energy planning has become important in developing countries and growing economies. The balance between energy production and consumption is based on good planning. The basis of the planning lies in high accuracy estimation, where time series techniques are often used. The Holt-Winters exponential smoothing method, which is one of the time series techniques and includes seasonality, was used in this study. In the study, genetic algorithm method was used to determine the parameters in Holt-Winters exponential smoothing (HWES) method and electrical load forecasts were made by using these parameters. Mean absolute deviation (MAD) was used as the optimization target function in parameter determination. The parameters determined by genetic algorithm were generated with 200 monthly data on a monthly basis and 12 month load values were used in the estimation. MAPE, MAD and MPE errors were shown in the study and the proposed approach was found to be suitable for the estimation of electrical load.
\end{abstract}

Keywords: Holt-Winters exponential smoothing method, genetic algorithm, energy, estimation of electrical load, Matlab.

\section{Elektrik Yükünün Genetik Algoritma Temelli Holt-Winters Üstel Düzeltme Yönteminiyle Tahmini}

Öz

Enerji planlaması gelişmekte olan ülkelerde ve büyüyen ekonomilerde önemli bir hâle gelmiştir. Enerji üretim ve tüketim dengesi bu planlamanın iyi yapılmasından geçmektedir. Planlamanın temelinde yüksek doğrulukta tahmin yatmaktadır ve burada genellikle zaman serileri teknikleri kullanılmaktadır. Zaman serisi tekniklerinden biri olan ve mevsimsellik içeren Holt-Winters üstel düzeltme yöntemi bu çalışmada kullanılmıştır. Yapılan çalışmada Holt-Winters üstel düzeltme (HWÜD) yöntemindeki parametrelerin tespit edilmesi genetik algoritma ile sağlanarak elektrik yük tahmini yapılmıştır. Parametre tespitinde optimizasyon hedef fonksiyonu olarak ortalama mutlak sapma (MAD) kullanılmıştır. Genetik algoritma ile belirlenen parametreler aylık bazda 200 aylık veri ile oluşturulmuştur ve 12 aylık yük değerleri de tahminde kullanılmıştır. Yapılan çalışmada MAPE, MAD ve MPE hataları gösterilmiş olup, önerilen yaklaşımın elektrik yük tahmininde uygun olduğu görülmüştür.

Anahtar Kelimeler: Holt-Winters üstel düzeltme yöntemi, genetik algoritma, enerji, yük tahmini, Matlab.

\section{Giriş}

Dünya genelindeki nüfus artışı, teknolojinin ilerlemesi, sanayinin büyümesi gibi sebepler enerji ihtiyacını gün geçtikçe artırmaktadır. Dünyanın gelişen ekonomileri arasında yer alan ülkemizde de enerjiye olan bu ihtiyacın arttığı görülmektedir ve bu ülkelerin başında gelmektedir [1]. 
Özger et. al

Enerjiye olan ihtiyacın artması ile doğru orantılı olarak bu enerjiyi karşılayabilmek için üretimin de artması gerekmektedir. Dünyada enerji üretiminde en büyük pay sahibi \%87 ile petrol, doğal gaz, kömür gibi fosil yakıtlardır. Geriye kalan \%13'lük kısmını ise nükleer enerji ve yenilenebilir kaynaklar oluşturmaktadır [2]. Ülkemizde elektrik üretimi 2018 verilerine göre, \%37.3’ü kömür, \%29.8'i doğal gaz, \%19.8'i hidrolik enerji, \%6.6's1 rüzgar, \%2.6's1 güneş, \%2.5'i jeotermal ve \%1.4'ü diğer enerji kaynaklarından elde edilmiştir [3]. Veriler incelendiğinde elektrik üretiminde en büyük pay sahibi fosil yakıtlar yani tükenebilir enerji kaynaklarıdır. Bu durum hem farklı enerji kaynakları bulmaya hem elektrik enerjisini iktisatlı kullanmaya [4] hem de enerji ihtiyacını önceden tahmin edip ona göre önlemler almaya sevk etmiştir. Türkiye’de ise enerjinin \%75’i ithal edilmektedir [5].

Talebin önceden kestirilmesi, tahmin edilmesi son zamanlarda çok önem kazanmıştır. İnsanların ihtiyaçlarının artması üreticilerin bu ihtiyaçları önceden tahmin edip ona göre bu ihtiyaçları karşılaması en önemli faktör haline gelmiştir. Bu durum insanları talep tahmini için birçok yazılım geliştirmeye sevk etmiştir. Netice olarak birçok tahmin yöntemi ortaya çıkmıştır. Bunlardan bazıları; Holt-Winters Üstel Düzeltme (HWÜD), ARIMA modelleri gibi zaman serisi teknikleri [6], Bulanık Mantık, Yapay Sinir Ağları gibi yapay zeka teknikleri [7], Genetik Algoritma gibi optimizasyon teknikleri [8], Regresyon gibi istatistiki modellerdir [9]. Bunlar da kendi içerisinde bölümlere ayrilmaktadır [10].

Holt-Winters Üstel Düzeltme yöntemi geçmiş zaman verilerini kullanarak gelecek dönemlere yönelik tahminler yapmaktadır. HWÜD yönteminin doğru tahminler yapabilmesi için bu yöntemde kullanılan katsayıların doğru tespit edilmesi gerekmektedir. Yapılan bu çalışmada HWÜD için önemli olan bu katsayıların genetik algoritma ile tespit edilmesi amaçlanmıştır.

\section{Literatür Çalışması}

Nüfusun artması, sanayi ve teknolojinin enerjinin önemini gün geçtikçe artırmaktadır [1]. Bununla birlikte elektrik üretiminde kullanılan kaynakların tükenebilir ve dışarıdan alınması insanları farklı çözüm yolları aramaya yönlendirmiştir. Bu çözüm yollarından bir tanesi üretim ve tüketim dengesinin sağlanmasıdır [11]. Tüketim miktarının önceden tahmin edilmesi elektrik üretiminde önceden tedbirler alınmasına büyük kolaylıklar sağlamaktadır [12]. Yani elektrik tahmininin gerçeğe yakın sonuçlar vermesi daha az elektrik kesintisi, daha az elektrik ücreti ve üretimde daha az tükenebilir kaynak kullanmak demektir [13]. Elektrik tahmininde birçok yöntem kullanılmaktadır. Genetik Algoritma ile elektrik tahmini [12], Yapay Sinir Ağları ile elektrik tahmini [14], ARIMA modeli ile elektrik tahmini [15], HWÜD Yöntemi ile elektrik tahmini bunlardan bazılarıdır [14].

HWÜD Yöntemi ve diğer tahmin yöntemlerinin karşılaştırıldığ 1 birçok çalışma yapılmıştır. Örneğin; Boltürk, elektrik talep tahmininde kullanılmak üzere Hareketli Ortalama, Üstel düzeltme, HWÜD yöntemi , ARIMA, Bulanık Mantık, Yapay Sinir Ağları ve regresyon yöntemlerine başvurmuştur. Çalışmalar sonucunda Holt-Winters yönteminin orta ve kısa vadeli tahminlerde düşük hatalı sonuçlar verdiği gözlemlenmiştir [14]. Akpınar ve Yumuşak ise doğal gaz sektörü için zaman serilerinin ayrıştırılması, HWÜD, SARIMA tekniklerini kullanarak şehir doğal gaz tahmininde bulunmuşlardır [16]. Yine Sosyal ve Ömürgönülşen, Türk turizm sektörü talep tahmini üzerine yaptıkları bir çalışmada Hareketli Ortalama, Basit Üstel Düzeltme, HWÜD zaman serisi yöntemlerini kullanmışlardır. Sonuçta HWÜD yönteminin mevsimsellik ve trend içerdiği için diğer yöntemlerden daha iyi sonuçlar verdiği gözlemlenmiştir [17]. Başka bir turizm modellemesinde Çuhadar, Muğla iline yönelik dış turizm talebinin modellenmesinde Üstel Düzeltme ve Box-Jenkins yöntemlerini kullanmıştır. En başarılı sonucu HWÜD yönteminin verdiği gözlemlenmiştir [18]. Başka bir çalışmada Irmak, Köksal ve Asilkan, hastanelerin gelecekteki hasta yoğunluklarının tahmin edilmesinde Üstel Düzeltme, ARIMA ve Yapay Sinir Ağları yöntemlerini kullanmışlardır. Belirlenen kriterlerin çoğunda HWÜD yöntemi başarılı sonuçlar gösterdiği gözlemlenmiş̧ir [19]. Bunların dışında bankaların altın rezervlerinin incelenmesi [20], doğal gaz talep tahmini [16,21], giyim endüstrisi talep tahmini [22], sosyal güvenliğin önemli değişkenlerinin analizi [23], su tüketimi tahmini [24], mobil ağalar için trafik tahmini [25], döviz kuru değişimlerini inceleme [26] daha birçok alanda çalışma yapılmıştır. 
Genetik Algoritma bir çok parametrenin değerini değiştirerek; bir değeri minimum, maksimum ve belirli bir değere getirmeye çalışan evrişimli bir algoritmadır. Maksimizasyon ve minimizasyon problemlerinin çözümünde çok büyük öneme sahiptir. Birçok alanda kullanılmaktadır. En çok bilinen gezgin satıcı problemidir [27]. Yine elektrik tahmininde [28], insansız hava araçlarında [29], acil servis sistemlerinde [30], demir yolu trafik kontrolünde [31] ve 1sı transferinde [32] kullanılmaktadır. $\mathrm{Bu}$ problemlerin önemli özelliği NP-Zor problem olmaları ve polinamiyel zamanda çözülememeleridir. Literatür taramasında HWÜD yöntemindeki parametrelerin genetik algoritma ile tespit edilmesi konusunda sadece bir çalışma yapılmış olup [33], Elektrik enerjisi tarafında ilk kez uygulanmıştır.

Çalışmanın 3. bölümünde HWÜD yöntemi, genetik algoritma ve hata terimi, 4. bölümde elektrik yük tahmini, veri ve HWÜD ile genetik algoritmanın entegrasyonu anlatılmışır. 5. bölümde elektrik tahmini yapılıp bulgular yorumlanmıştır. 6. bölümde ise yapılan çalışmanın değerlendirmesi yapilacaktır.

\section{Metotlar}

\subsection{Winters Üstel Düzleștirme Metodu}

Winters Üstel Düzeltme Yöntemi, verilerdeki son değişimleri ve sıçramaları nazarı dikkate almaktadır. $\mathrm{Bu}$ sıçramalar, rasgele değişimler, açıklanamayan etkiler ve önceden sezilemeyen gözden kaçırılmış gelişmelerden oluşmaktadır. Geçmiş dönem değerlerinin ağırlıklı ortalaması alınarak gelecek dönem tahmin değeri olarak kullanılmaktadır. Bu yöntemde, yakın geçmiş verilerinin geleceğe etkisi eski döneme göre daha fazladır. Yani yakın geçmişteki dönemden eski döneme gidildikçe üstel azalan ağırlıklar verilmektedir [18].

Winters Üstel Düzeltme Yöntemi, trend ve mevsimsel etki içinde barındıran zaman serilerinde kullanmak için geliştirilmiştir. Bu yöntemi serinin trendine, ortalama düzeyine ve mevsimsel bileşenine uygulamak mümkündür [19].

Holt'un iki parametre modeline mevsimselliğin eklenmesiyle oluşmuştur. Bu yüzden Holt-Winters yöntemi diye de adlandırılır. Bu yöntemde kullanılan denklemler aşağıda verilmiştir [34]. Surasıyla $S_{t}$ geçmiş veri ile ilişkisi (1), $b_{t}$ trenti (2), $I_{t}$ mevsimsel ilişkiyi (3) göstermektedir. Nihai tahminler ise (4) kullanılarak belirlenmektedir.

$$
\begin{aligned}
& S_{t}=\alpha \cdot\left(\frac{Y_{t}}{I_{t-L}}\right)+(1-\alpha) \cdot\left(S_{t-1}+b_{t-1}\right) \\
& b_{t}=\beta \cdot\left(S_{t}-S_{t-1}\right)+(1-\beta) \cdot b_{t-1} \\
& I_{t}=\gamma \cdot\left(\frac{Y_{t}}{S_{t}}\right)+(1-\gamma) \cdot I_{t-L} \\
& \overline{Y_{t+m}}=\left(S_{t}+b_{t} \cdot m\right) \cdot I_{t-L+m}
\end{aligned}
$$

Bu denklemlerde;

$Y_{t}=\mathrm{t}$ dönem sonunda gerçek talep değeri

$\alpha=$ St için kullanılan düzleştirme sabiti $(0<\alpha<1)$

$S_{t}=$ mevsimsel tahmini 
$\beta=$ trend tahmini için düzleştirme sabiti $(0<\beta<1)$

$b_{t}=$ trend tahmin değeri

$I_{t-L}=\mathrm{L}$ dönem önceki düzleştirilmiş mevsimsel indeks

$\mathrm{L}=$ mevsimsel döngünün uzunluğu (örneğin 12 ay veya dört çeyrek)

$\gamma=$ mevsimsellik tahmini için düzleştirme sabiti $(0<\gamma<1)$

$I_{t}=\mathrm{t}$ dönem sonunda düzleştirilmiş mevsimsel indeks

$\mathrm{M}=Y_{t}+\mathrm{m}$ tahminin ufuk uzunluğu (genişliği)

olmaktadır. HWÜD yönteminde düzleştirme katsayı değerlerinin belirlenmesi çok önem arz etmektedir. Bu katsayıların belirlenmesindeki gaye; bu yöntemin hata kareleri ortalamalarını en küçük yapacak düzleştirme değerlerini elde etmektir.

\subsection{Genetik Algoritma}

Genetik Algoritma, canlıların yaşam serüvenini göz önünde bulundurur. Nesil olarak iyi olanlar yaşamlarını korur ama iyi olmayan (kötü) nesiller yaşamlarını koruyamaz ve yok olurlar. Genetik algoritma bu prensipler çerçevesinde hareket eder. Modelleme işleminin matematiksel olarak yapılamadığı net bir çözümün olmadığı kısıtlı problemlerin çözümünde kullanılır [35].

Genetik Algoritma modelleme ve problem çözme alanlarında kullanılırken bugün kullanım alanları gittikçe genişlemektedir. Mesela; Gezgin Satıcı Problemi, Makine ve Robot Öğrenmesi, Optimizasyon, Finans ve Pazarlama, Elektronik Devre Tasarımı, Görüntü kontrolü, Yapay Sinir Ağları, Paketleme Problemleri gibi alanlarda kullanılmaktadır [36].

Genetik algoritmalar çaprazlama ve çaprazlama oranı, mutasyon ve mutasyon oranı, popülasyon büyüklüğü, seçim, kodlama gibi parametrelerden oluşmaktadır [37]. Çaprazlama oranı yüksek olmakla beraber mutasyon oranı çok düşük olmalıdır. Yine çok büyük bir popülasyon büyüklüğü çoğunlukla çözüm hızı bakımından GA'yı değiştirmez. Seçim noktasında çoğunlukla rulet tekerleği kullanılır, bununla birlikte elitizm, rank seçimi ve kararlı durum yöntemleri de kullanılır [35].

\subsection{Hata Ölçütleri}

Hata ölçütleri, zaman serisinin gerçek davranışı ile tahmin değerleri arasındaki ilişkileri yorumlamamızı sağlar ve en iyi düzeltme sabitlerini bulamamıza yardımcı olur. Talep tahminlerinde en çok kullanılan hata ölçütleri; ortalama mutlak sapma (mean absolute deviation-MAD) (5), ortalama mutlak yüzde hata (mean absolute percetage error-MAPE) (7), ortalam yüzde hata (mean percetage error-MPE) (6) ve ortalama hata kareler(mean squared error-MSE) değerleridir [17].

$$
\begin{gathered}
M A D=\left(\frac{1}{n}\right) \cdot \sum_{t=1}^{n}\left|Y_{t}-\overline{Y_{t}}\right| \\
M P E=\left(\frac{1}{n}\right) \cdot \sum\left(\frac{Y_{t}-\bar{Y}_{t}}{Y_{t}}\right) \cdot 100 \\
M A P E=\sum_{t=1}^{n} \frac{\left|Y_{t}-\overline{Y_{t}}\right|}{Y_{t}} \cdot 100
\end{gathered}
$$

Bu denklemlerdeki değerler; 
$Y_{t}=$ Gerçek değer

$\overline{Y_{t}}=$ Tahmin değeri

$\mathrm{n}=$ dönem sayıs1

olmaktadır.

\section{Elektrik Yük Tahmini}

Talep tahmini, geçmişteki verileri kullanarak gelecek yıllarda ne kadar ihtiyacı olabilir ve bu ihtiyaca karşı önceden nasıl önlemler alınabilir sorularının cevaplandırılmasına büyük kolaylık sağlar. $\mathrm{Bu}$ bölümde kullanılan veri, HWÜD ile genetik algoritmanın entegrasyonu anlatılacaktır.

\subsection{Veri}

ABD Enerji Bilgi İdaresi (EIA) yakın tarih ve geçmiş enerji istatistiksel verileri kullanılarak bu elektrik yük tahmini yapılmıştır*. Burada 11 farklı veriseti elde edilmiştir. Bu verisetleri Tablo 1'de gösterilmiştir. Bu verisetlerinde 18 yıllık veri aylık bazda kullanılmıştır. Veri tahminleri hem aylık hem de çeyreklikler ile yapıldığı için 22 farklı veriseti elde edilmiştir. 11 farklı üretim kaynakları göz önüne alınarak onların yıllara göre üretim verileri kullanılarak tahminler yapılmıştır. Bu tahminlerde yıllık ve çeyrek dönmelik veriler kullanılmıştır.

Tablo 1 Kullanılan Veriseti

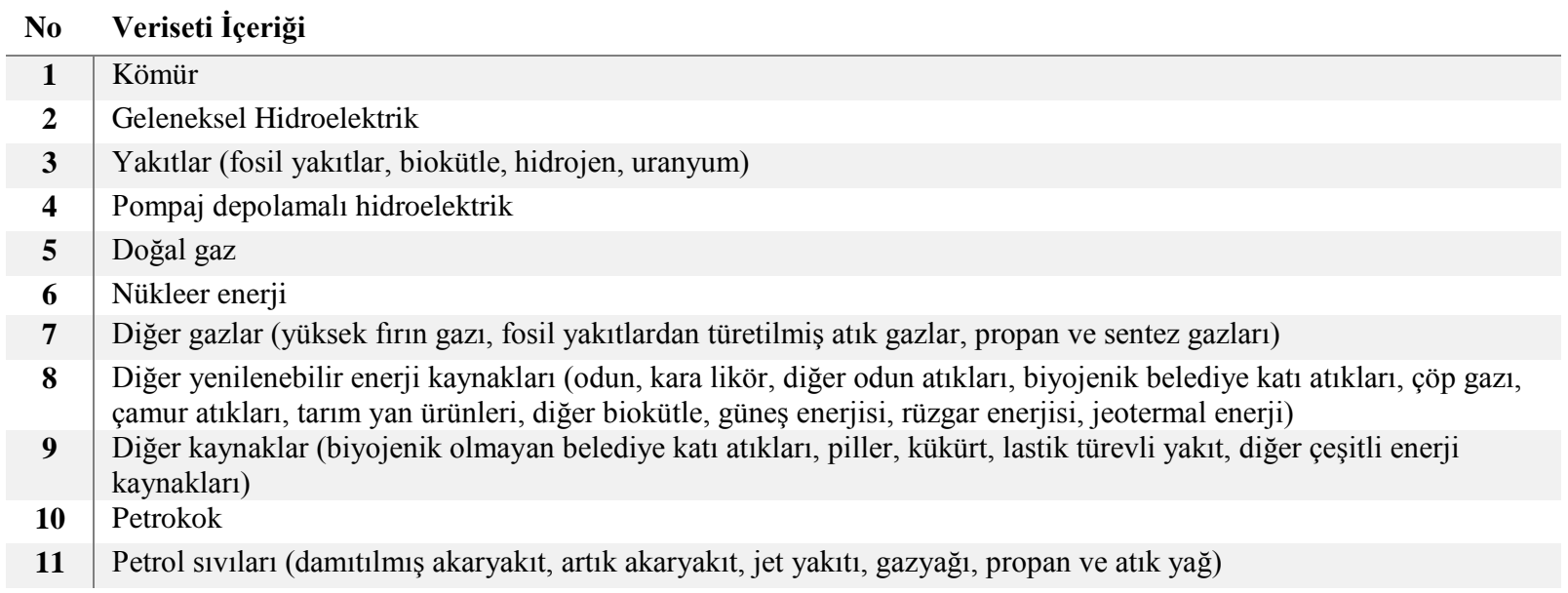

\subsection{Holt-Winters Üstel Düzeltme Yönteminin Gerçekleștirilmesi}

HWÜD yöntemi modelinin bilgisayar ortamına aktarılmasıyla Matlab programı kullanılmıştır. İlk olarak HWÜD yöntemiyle ilgili bir örnek [34] Matlab programında kodlanmıştır. Daha sonra bu program geliştirilerek başka bir örnekte uygulanabilecek seviye getirilmiştir. Winters yönteminin doğru tahminler yapabilmesi için $\alpha, \beta$ ve $\gamma$ katsayılarının uygun olması gerekmektedir. Elde edilen

https://www.eia.gov/electricity/data/browser/\#/topic/0?agg=2,0,1\&fuel=vvg\&geo=g\&sec=00g\&linech art=ELEC.GEN.ALL-US-94.M ELEC.GEN.COW-US-94.M ELEC.GEN.NG-US-

94.M ELEC.GEN.NUC-US-94.M ELEC.GEN.HYC-US-94.M\&columnchart=ELEC.GEN.ALL-US94.M ELEC.GEN.COW-US-94.M ELEC.GEN.NG-US-94.M ELEC.GEN.NUC-US-

94.M ELEC.GEN.HYC-US-94.M\&map=ELEC.GEN.ALL-US94.M\&freq=M\&start=200101\&end=201903\&ctype=linechart\&ltype=pin\&rtype=s\&maptype=0\&rse= $\underline{0 \& p i n=}$ 
sonuçlar ile olması gereken sonuçlar karşılaştırılmış, tekniğin doğru kodlandığ belirlendikten sonra genetic algoritmalar ile optimizasyon aşamasına geçilmiştir.

\subsection{Holt-Winters ile Genetik Algoritma Entegreasyonu}

$\mathrm{Bu}$ aşamanın öncesinde; ilk olarak Genetik Algoritma Matlab programında kodlanmıştır. Programlama aşamasında amaç fonksiyonu, hata kriterlerinin minimizasyonu olarak belirlenmiştir. Doğal seçilimde Rulet Çarkı yöntemi ve çaprazlamada Tek Noktalı Çaprazlama yöntemleri kullanılmıştır. Bitiş kriteri olarak bir iterasyon sayısı belirlenmiştir (programda bu sayının kullanıcı tarafından girilmesi istenmiştir.). Bu bilgiler ışığında alt program fonksiyonu olarak kodlanan genetik algoritma adımları ana fonksiyonla yani Winters programıla birleştirilmiştir (Şekil 1). Bu birleşimle ortaya en iyi $\alpha, \beta$, ve $\gamma$ değerlerini bulmaya çalışan ve gerçek değerlere en yakın tahminler üretmesi istenen bir program çıkmıştır.

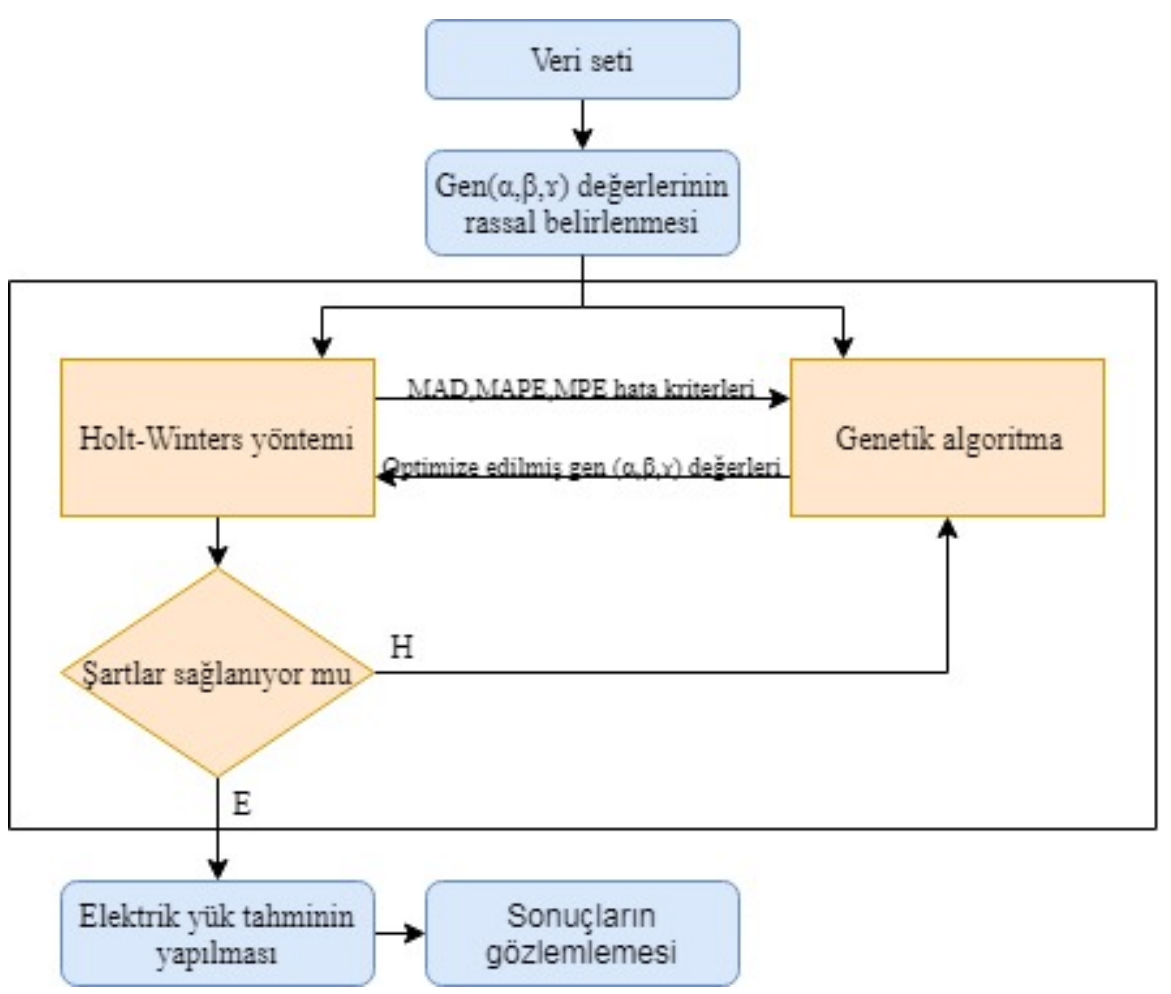

Şekil 1 Holt-Winters ve Genetik Algoritma yöntemlerinin entegrasyonu

\section{Bulgular}

Tahminlerde 18 yıllık veriler kullanılarak modeler elde edilmiştir. 12 aylık ve çeyrek dönemlik tahminler gerçekleștirilerek test işlemi yapılmıştır. 22 farklı veri seti üzerinde iki farklı seri davranışı incelenmiştir. En iyi sonuç 12 aylık tahmin modeli olan nükleer enerji tahmininde (Şekil 3(f)), en kötü sonuç çeyrek dönem tahmin modeli olan petrokok tahmininde (Şekil 4(j)) ortaya çıkmıştır.

Nükleer Enerji ile elektrik üretimi serisinde yapılan model çalışmasında 500 iterasyonluk gerçekleştirilen eğitimde 11 iterasyondan sonra değişikliğin fazla olmadığ́ görülmüştür(Şekil 2). Diğer üretim serilerinde de aynı sonuç görülmüştür. 


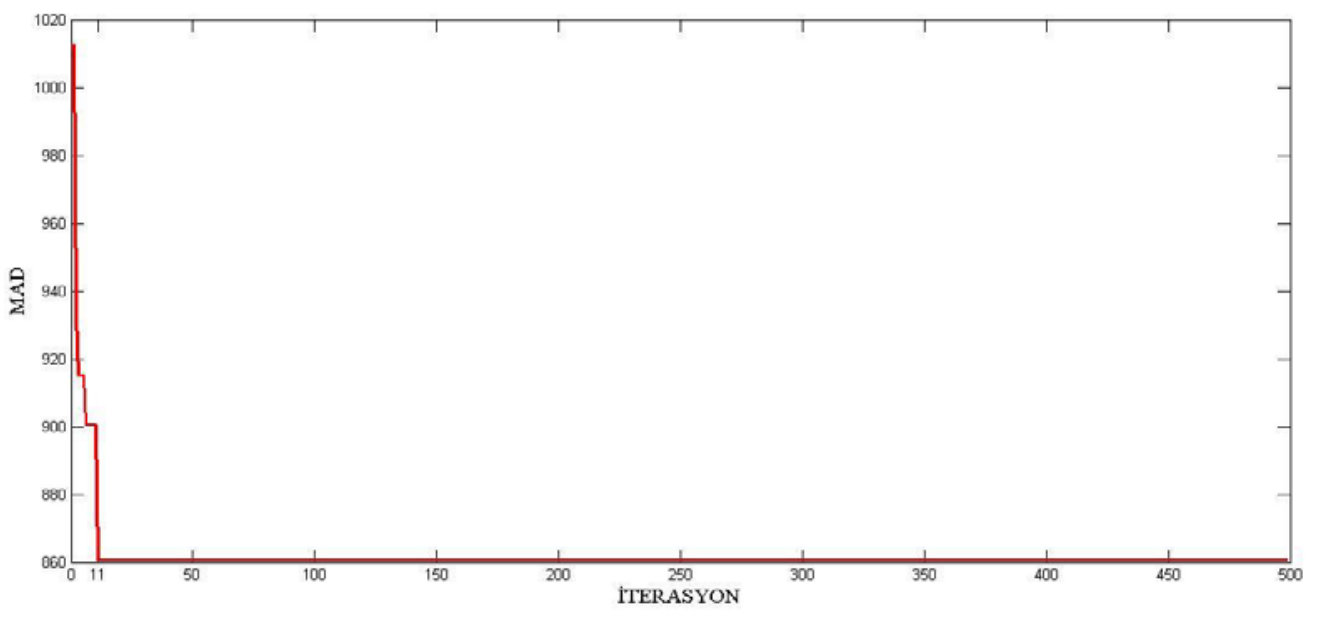

Şekil 2 Nükleer Enerji İterasyon-MAD grafiği

Modellerin eğitim aşamasından sonra test aşamasına geçilmiştir. Bu sonuçlar şekil 4, şekil 5 ve tablo 2'de gösterilmiştir.

\subsection{Aylık tahmin}

Kömür ile elektrik üretimi serisinde yapılan model çalışmasında 500 iterasyonluk gerçekleştirilen eğitimde 10 iterasyondan sonra değişikliğin fazla olmadığı görülmüş̧ür. Bu sonuçlar Şekil 3(a) ve Tablo 2'de gösterilmiştir. Ayrıca $\alpha, \beta$ ve $\gamma$ değerleri sırasıyla 0.553 , 0.008 ve 0.565 olarak tespit edilmiştir. Tablo 2'ye bakıldığında hata yüzdelerinden MAPE'nin düşük çıktı̆̆ 1 görülmektedir. Hata yüzdelerinin düşük çıkması Şekil 3(a)'ya bakıldığında gerçek değerlerle tahmin değerlerinin büyük ölçüde örtüştügünü göstermektedir.

Hidroelektrik ile elektrik üretimi serisinde yapılan model çalışmasında 500 iterasyonluk gerçekleştirilen eğitimde 10 iterasyondan sonra değişikliğin fazla olmadığı görülmüştür. Bu sonuçlar Şekil3(b) ve Tablo 2'de gösterilmiştir. Ayrıca $\alpha, \beta$ ve $\gamma$ değerleri sırasıyla 0.846, 0.106 ve 0.470 olarak tespit edilmiştir. Tablo 2'ye bakıldığında eğitim aşamasında hata yüzdelerinden MAPE düşük seyrederken test aşamasında yükselmiştir. Hata yüzdelerinin düşük çıkması Şekil 3(b)'ye bakıldığında gerçek değerlerle tahmin değerleri eğitim aşamasında büyük oranda örtüşürken test aşamasında sapma olmuştur.

Yakıtlar ile elektrik üretimi serisinde yapılan model çalışmasında 500 iterasyonluk gerçekleştirilen eğitimde 11 iterasyondan sonra değişikliğin fazla olmadığı görülmüştür. Bu sonuçlar Şekil 3(c) ve Tablo 2'de gösterilmiştir. Ayrıca $\alpha, \beta$ ve $\gamma$ değerleri sırasıyla $0.40,0.016$ ve 0.243 olarak tespit edilmiş̧ir. Tablo 2'ye bakıldı ğında hem eğitim hem de test aşamasında hata yüzdelerinden MAPE çok düşük seyretmektedir. Hata yüzdelerinin düşük çıkması Şekil 3(c)'ye bakıldığında gerçek değerlerle tahmin değerleri hem eğitim hem de test aşamasında büyük oranda örtüştügü görülmüştür. Yani tahmin değerleri gerçek değerlere çok yakın sonuçlar vermiştir.

Pompaj depolamalı hidroelektrik ile elektrik üretimi serisinde yapılan model çalışmasında 500 iterasyonluk gerçekleştirilen eğitimde 10 iterasyondan sonra değişikliğin fazla olmadığı görülmüştür. Bu sonuçlar Şekil 3(d) ve Tablo 2'de gösterilmiştir. Ayrıca $\alpha, \beta$ ve $\gamma$ değerleri sırasıyla $0.51,0.568$ ve 0.177 olarak tespit edilmiştir. Tablo 2'ye bakıldığında eğitim aşamasında hata yüzdelerinden MAPE yüksek seyrederken test aşamasında düşmüştür. Şekil 3(d)'ye bakıldığında gerçek değerlerle tahmin değerleri arasında eğitim aşamasının dörtte üçünde sapmalar meydana gelirken diğer kısım ve test aşamasında büyük oranda örtüşme görülmektedir.

Doğal gaz ile elektrik üretimi serisinde yapılan model çalışmasında 500 iterasyonluk gerçekleştirilen eğitimde 10 iterasyondan sonra değişikliğin fazla olmadığı görülmüş̧ür. Bu sonuçlar Şekil 3(e) ve Tablo 2'de gösterilmiştir. Ayrıca $\alpha, \beta$ ve $\gamma$ değerleri sırasıyla $0.739,0.057$ ve 0.640 olarak tespit edilmiştir. Tablo 2'ye bakıldığında hem eğitim hem de test aşamasında hata yüzdelerinden MAPE çok 
düşük seyretmektedir. Şekil 3(e)'ye bakıldığında gerçek değerlerle tahmin değerleri eğitim aşamasında büyük oranda örtüşürken test aşamasında düşük oranda bir sapma meydana gelmiştir. Yani tahmin değerleri gerçek değerlere çok yakın sonuçlar vermiştir.

Nükleer enerji ile elektrik üretimi serisinde yapılan model çalışmasında 500 iterasyonluk gerçekleştirilen eğitimde 10 iterasyondan sonra değiş̧ikliğin fazla olmadığı görülmüştür. Bu sonuçlar Şekil 3(f) ve Tablo 2'de gösterilmiştir. Ayrıca $\alpha, \beta$ ve $\gamma$ değerleri sırasıyla 0.739. 0.082 ve 0.259 olarak tespit edilmiştir. Tablo 2'ye bakıldığında hem eğitim hem de test aşamasında hata yüzdelerinden MAPE çok düşük seyretmektedir. Şekil 3(f)'ye bakıldığında gerçek değerlerle tahmin değerleri hem eğitim hem de test aşamasında büyük oranda örtüştüğü görülmektedir. Yani tahmin değerleri gerçek değerlere çok yakın sonuçlar vermiştir.

Diğer gazlar ile elektrik üretimi serisinde yapılan model çalışmasında 500 iterasyonluk gerçekleştirilen eğitimde 11 iterasyondan sonra değişikliğin fazla olmadığı görülmüştür. Bu sonuçlar Şekil 3(g) ve Tablo 2'de gösterilmiştir. Ayrıca $\alpha, \beta$ ve $\gamma$ değerleri sırasıyla $0.495,0.0036$ ve 0.980 olarak tespit edilmiştir. Tablo 2'ye bakıldığında eğitim aşamasında hata yüzdelerinden MAPE yüksek seyrederken test aşamasında düşmüştür. Şekil 3(g)'ye bakıldığında gerçek değerlerle tahmin değerleri arasında eğitim aşamasının yarısında sapmalar meydana gelirken diğer yarısında ve test aşamasında büyük oranda örtüşme görülmektedir.

Diğer yenilenebilir kaynaklar ile elektrik üretimi serisinde yapılan model çalışmasında 500 iterasyonluk gerçekleştirilen eğitimde 11 iterasyondan sonra değişikliğin fazla olmadığı görülmüştür. Bu sonuçlar Şekil 3(h) ve Tablo 2'de gösterilmiştir. Ayrıca $\alpha, \beta$ ve $\gamma$ değerleri sırasıyla $0.071,0.322$ ve 0.358 olarak tespit edilmiştir. Tablo 2'ye bakıldığında hem eğitim hem de test aşamasında hata yüzdelerinden MAPE çok düşük seyretmektedir. Şekil 3(h)'ye bakıldığında gerçek değerlerle tahmin değerleri hem eğitim hem de test aşamasında büyük oranda örtüştüğ̈ görülmektedir.

Diğer kaynaklar ile elektrik üretimi serisinde yapılan model çalışmasında 500 iterasyonluk gerçekleştirilen eğitimde 11 iterasyondan sonra değiş̧ikliğin fazla olmadığı görülmüştür. Bu sonuçlar Şekil 3(i) ve Tablo 2'de gösterilmiştir. Ayrıca $\alpha, \beta$ ve $\gamma$ değerleri sırasıyla $0.656,0.024$ ve 0.2208 olarak tespit edilmiştir.Tablo 2'ye bakıldığında hem eğitim hem de test aşamasında hata yüzdelerinden MAPE çok düşük seyretmektedir. Şekil 3(i)'ye bakıldığında gerçek değerlerle tahmin değerleri eğitim aşamasında büyük oranda örtüşürken test aşamasında meydana gelen sapmadan dolayı gerçek değer ile tahmin değerleri düşük oranda örtüşmektedir.

Petrokok ile elektrik üretimi serisinde yapılan model çalışmasında 500 iterasyonluk gerçekleştirilen eğitimde 11 iterasyondan sonra değişikliğin fazla olmadığ1 görülmüş̧ür. Bu sonuçlar Şekil 3(j) ve Tablo 2'de gösterilmiştir. Ayrıca $\alpha, \beta$ ve $\gamma$ değerleri sırasıyla $0.631,0.127$ ve 0.613 olarak tespit edilmiştir. Tablo 2'ye bakıldığında hem eğitim hem de test aşamasında hata yüzdelerinden MAPE çok yüksek seyretmektedir. Şekil 4(j)'ye bakıldığında gerçek değerlerle tahmin değerleri eğitim aşamasının dörtte birlik bölümünde örtüşürken diğer bölümde ve test aşamasında yüksek oranda sapmalar olmuştur. Yani doğru tahmin sonuçları verememiştir.

Petrol sıvıları ile elektrik üretimi serisinde yapılan model çalışmasında 500 iterasyonluk gerçekleştirilen eğitimde 11 iterasyondan sonra değiş̧ikliğin fazla olmadığ 1 görülmüsştür. Bu sonuçlar Şekil 4(k) ve Tablo 2'de gösterilmiştir. Ayrıca $\alpha, \beta$ ve $\gamma$ değerleri sırasıyla $0.711,0.063$ ve 0.598 olarak tespit edilmiştir. Tablo 2'ye bakıldığında hem eğitim hem de test aşamasında hata yüzdelerinden MAPE çok yüksek seyretmektedir. Şekil 3(k)'ya bakıldığında gerçek değerlerle tahmin değerleri eğitim aşamasının dörtte birlik bölümünde örtüşürken diğer bölümde ve test aşamasında yüksek oranda sapmalar olmuştur.

11 ayrı veri setinde 12 aylık dönemde sezonsallık değerleri $(\gamma)$ beklenildiği gibi düşük seyretmektedir ve birbirine yakın sonuçlar vermektedir. 
Özger et. al

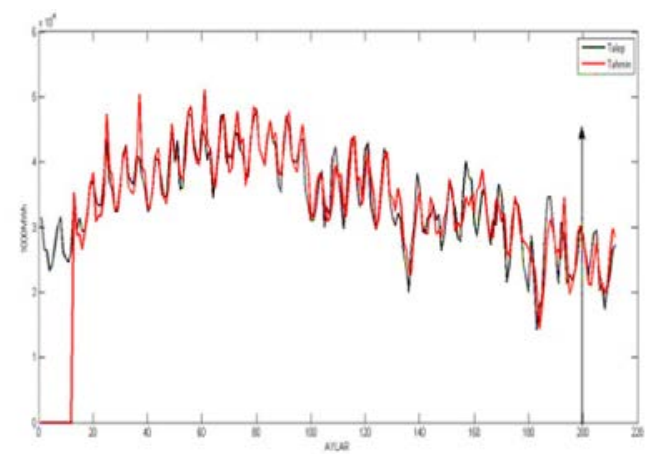

(a)

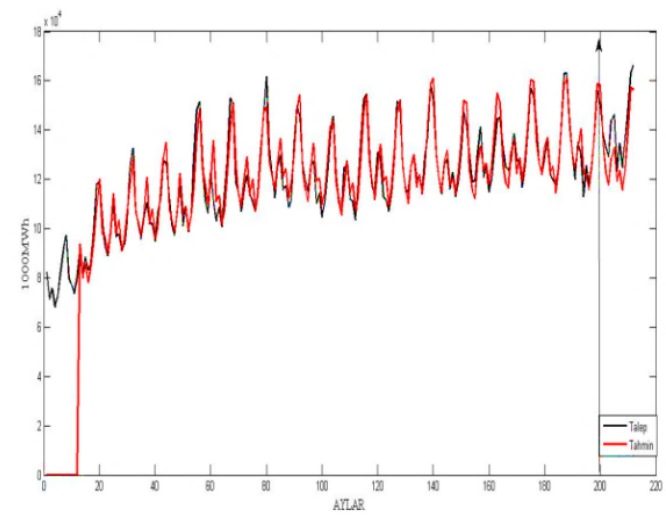

(c)

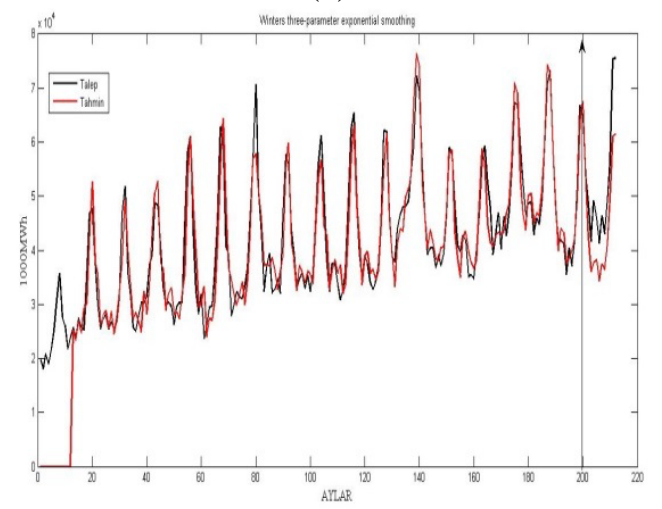

(e)

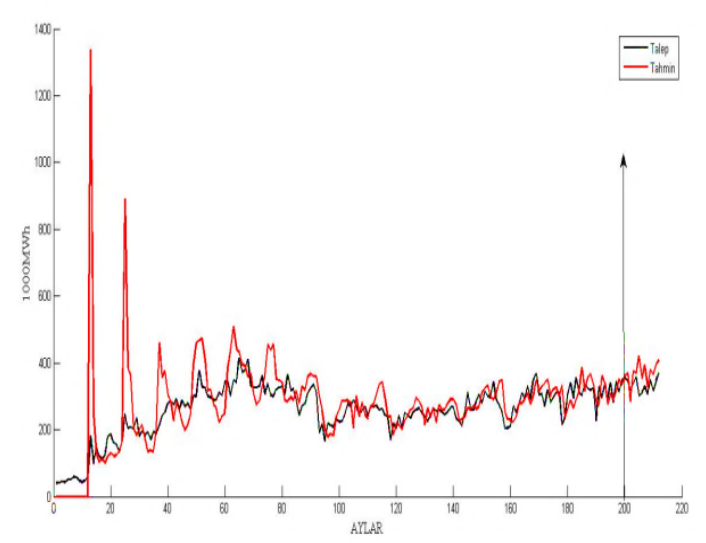

(g)

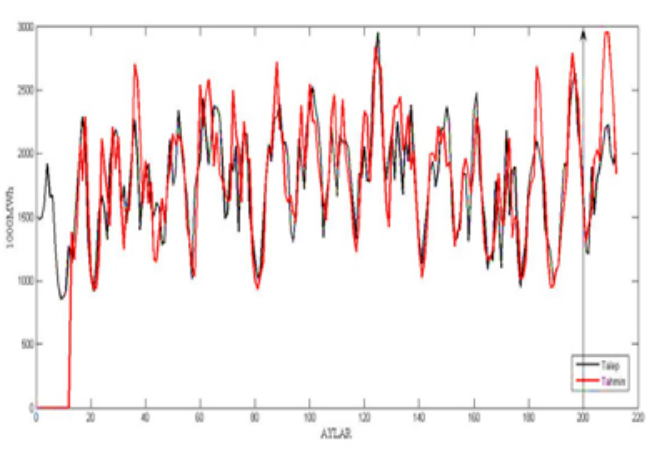

(b)

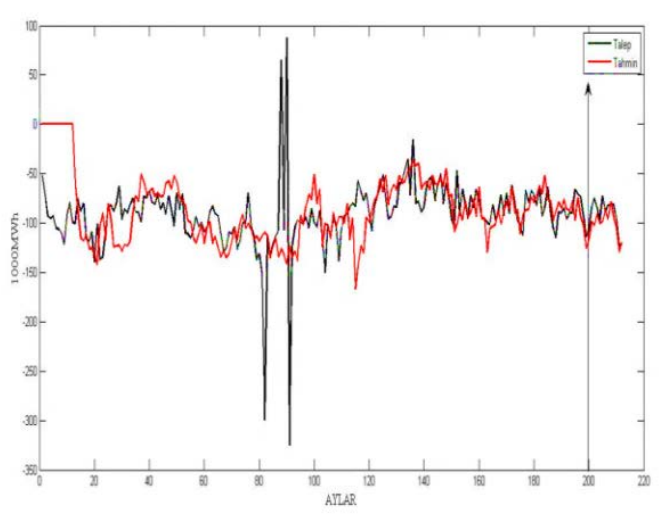

(d)

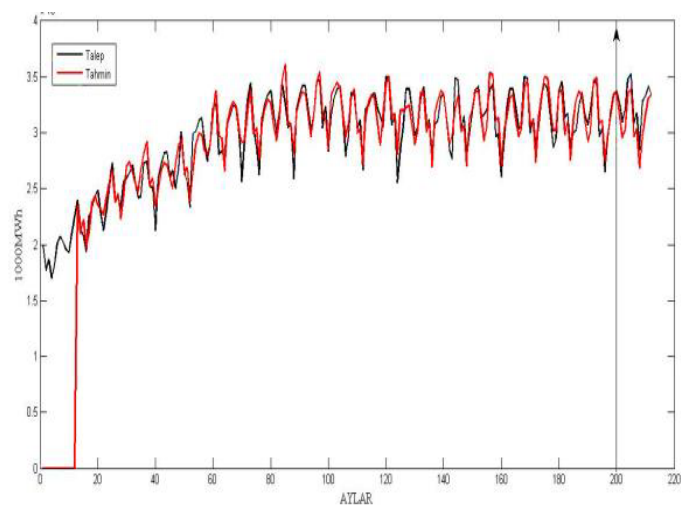

(f)

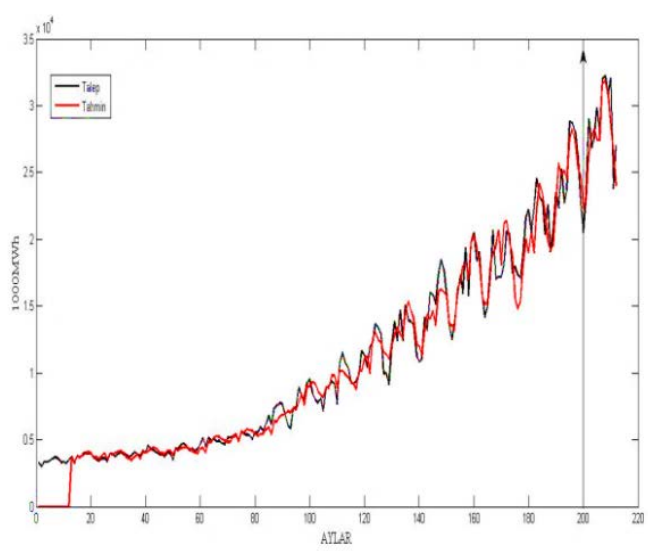

(h) 


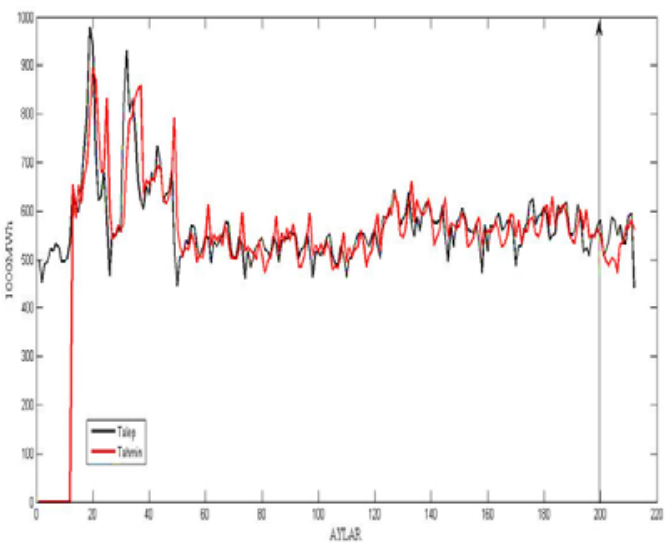

(i)

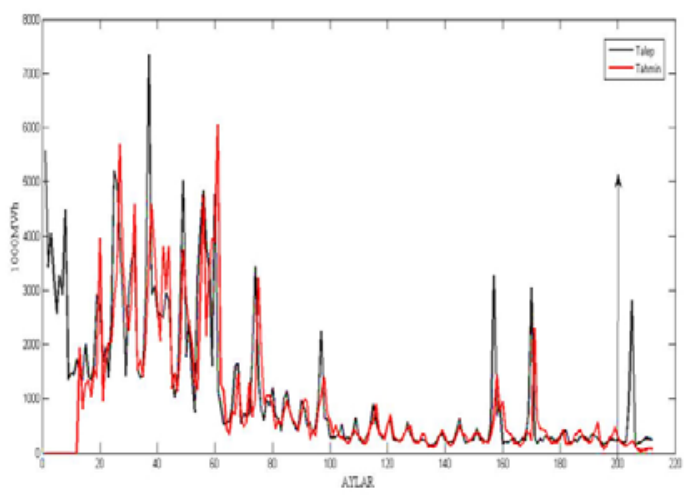

(k)

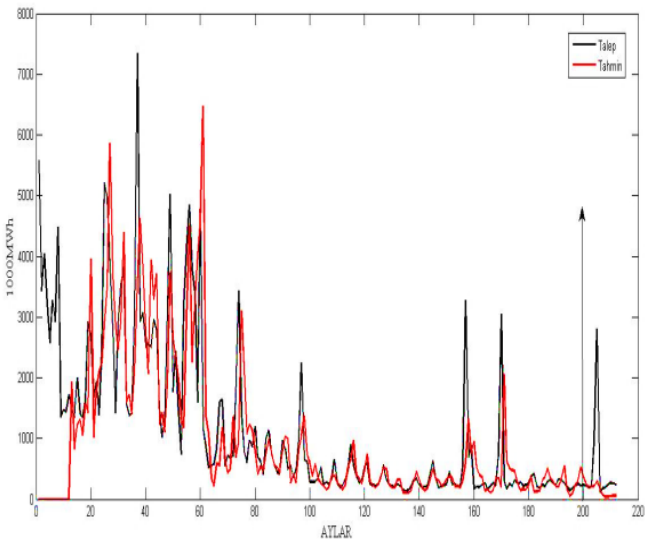

(j)

Şekil 3 Aylık elektrik üretimleri ve tahmin sonuçları (a) Kömür, (b) Hidrelektrik, (c) Yakıtlar, (d) Pompaj depolamalı hidroelektrik, (e) Doğal gaz, (f) Nükleer enerji, (g) Diğer gazlar, (h) Diğer yenilenebilir enerji kaynakları, (i) Diğer kaynaklar, (j) Petrokok, (k) Petrol sıvıları.

\section{2 Çeyrek dönemlik tahmin}

Kömür ile elektrik üretimi serisinde yapılan model çalışmasında 500 iterasyonluk gerçekleştirilen eğitimde 10 iterasyondan sonra değiş̧ikliğin fazla olmadığı görülmüştür. Bu sonuçlar Şekil 4(a) ve Tablo 2'de gösterilmiştir. Ayrıca $\alpha, \beta$ ve $\gamma$ değerleri sırasıyla $0.522,0.344$ ve 0.459 olarak tespit edilmiştir. Şekil 4(a)'ya bakıldığında gerçek değerlerle tahmin değerleri arasında eğitim aşamasında sapmalar meydana gelirken test aşamasında örtüşme görülmektedir.

Hidroelektrik ile elektrik üretimi serisinde yapılan model çalışmasında 500 iterasyonluk gerçekleştirilen eğitimde 10 iterasyondan sonra değiş̧ikliğin fazla olmadığı görülmüştür. Bu sonuçlar Şekil 4(b) ve Tablo 2'de gösterilmiştir. Ayrıca $\alpha$, $\beta$ ve $\gamma$ değerleri sırasıyla 0.029, 0.347 ve 0.442 olarak tespit edilmiştir. Tablo 2'ye bakıldığında hem eğitim aşamasında hem de test aşamasında MAPE değerleri biraz yüksek seyretmiştir. Hata yüzdelerinin biraz yüksek çıkması Şekil 4(b)’ye bakıldığında gerçek değerlerle tahmin değerleri hem eğitim hem de test aşamasında düşük oranda örtüşmesine yol açmıştır.

Yakıtlar ile elektrik üretimi serisinde yapılan model çalışmasında 500 iterasyonluk gerçekleştirilen eğitimde 11 iterasyondan sonra değişikliğin fazla olmadığı görülmüştür. Bu sonuçlar Şekil 4(c) ve Tablo 2'de gösterilmiştir. Ayrıca $\alpha, \beta$ ve $\gamma$ değerleri sırasıyla $0.418,0.123$ ve 0.742 olarak tespit edilmiştir. Tablo 2'ye bakıldığında hem eğitim hem de test aşamasında hata yüzdelerinden MAPE çok düşük seyretmektedir. Şekil 4(c)'ye bakıldığında gerçek değerlerle tahmin değerleri hem eğitim hem de test aşamasında büyük oranda örtüşmektedir. 
Özger et. al

Pompaj depolamalı hidroelektrik ile elektrik üretimi serisinde yapılan model çalışmasında 500 iterasyonluk gerçekleştirilen eğitimde 10 iterasyondan sonra değişikliğin fazla olmadığı görülmüştür. Bu sonuçlar Şekil 4(d) ve Tablo 2'de gösterilmiştir. Ayrıca $\alpha$, $\beta$ ve $\gamma$ değerleri sırasıyla 0.165, 0.025 ve 0.170 olarak tespit edilmiştir. Tablo 2'ye bakıldığında eğitim aşamasında hata yüzdelerinden MAPE yüksek seyrederken test aşamasında düşmüştür. Şekil 4(d)'ye bakıldığında gerçek değerlerle tahmin değerleri arasında eğitim aşamasının dörtte üçünde sapmalar meydana gelirken diğer kısım ve test aşamasında büyük oranda örtüşme görülmektedir.

Doğal gaz ile elektrik üretimi serisinde yapılan model çalışmasında 500 iterasyonluk gerçekleştirilen eğitimde 10 iterasyondan sonra değişikliğin fazla olmadığ görülmüştür. Bu sonuçlar Şekil 4(e) ve Tablo 2'de gösterilmiştir. Ayrıca $\alpha, \beta$ ve $\gamma$ değerleri sırasıyla $0.724,0.043$ ve 0.375 olarak tespit edilmiştir. Tablo 2'ye bakıldığında hem eğitim hem de test aşamasında hata yüzdelerinden MAPE çok düşük seyretmektedir. Şekil 4(e)'ye bakıldığında gerçek değerlerle tahmin değerleri eğitim aşamasında büyük oranda örtüşürken test aşamasında düşük oranda bir sapma meydana gelmiştir. Yani tahmin değerleri gerçek değerlere çok yakın sonuçlar vermiştir.

Nükleer enerji ile elektrik üretimi serisinde yapılan model çalışmasında 500 iterasyonluk gerçekleştirilen eğitimde 10 iterasyondan sonra değişikliğin fazla olmadığı görülmüsstür. Bu sonuçlar Şekil 4(f) ve Tablo 2'de gösterilmiştir. Ayrıca $\alpha$, $\beta$ ve $\gamma$ değerleri sırasıyla 0.250, 0.343 ve 0,202 olarak tespit edilmiştir. Tablo 2'ye bakıldı̆̆ında hem eğitim hem de test aşamasında hata yüzdelerinden MAPE çok düşük seyretmektedir. Şekil 4(f)'ye bakıldığında gerçek değerlerle tahmin değerleri hem eğitim hem de test aşamasında büyük oranda örtüştüğü görülmektedir. Yani tahmin değerleri gerçek değerlere çok yakın sonuçlar vermiştir.

Diğer gazlar ile elektrik üretimi serisinde yapılan model çalışmasında 500 iterasyonluk gerçekleştirilen eğitimde 11 iterasyondan sonra değişikliğin fazla olmadığ 1 görülmüştür. Bu sonuçlar Şekil 4(g) ve Tablo 2'de gösterilmiştir. Ayrıca $\alpha, \beta$ ve $\gamma$ değerleri sırasıyla $0.182,0.674$ ve 0.679 olarak tespit edilmiştir. Şekil 4(g)'ye bakıldığında gerçek değerlerle tahmin değerleri arasında eğitim aşamasında sapmalar meydana gelirken test aşamasında düşük oranda örtüşme görülmektedir.

Diğer yenilenebilir kaynaklar ile elektrik üretimi serisinde yapılan model çalışmasında 500 iterasyonluk gerçekleştirilen eğitimde 11 iterasyondan sonra değişikliğin fazla olmadığı görülmüsstür. Bu sonuçlar Şekil 4(h) ve Tablo 2'de gösterilmiştir. Ayrıca $\alpha, \beta$ ve $\gamma$ değerleri sırasıyla 0.152, 0.406 ve 0.752 olarak tespit edilmiştir. Tablo 2'ye bakıldığında hem eğitim hem de test aşamasında hata yüzdelerinden MAPE çok düşük seyretmektedir. Şekil 4(h)'ye bakıldığında gerçek değerlerle tahmin değerleri hem eğitim hem de test aşamasında büyük oranda örtüştüğü görülmektedir. Yani tahmin değerleri gerçek değerlere çok yakın sonuçlar vermiştir.

Diğer kaynaklar ile elektrik üretimi serisinde yapılan model çalışmasında 500 iterasyonluk gerçekleştirilen eğitimde 11 iterasyondan sonra değişikliğin fazla olmadığı görülmüş̧ür. Bu sonuçlar Şekil 4(i) ve Tablo 2'de gösterilmiştir. Ayrıca $\alpha, \beta$ ve $\gamma$ değerleri sırasıyla $0.172,0.627$ ve 0.712 olarak tespit edilmiş̧ir. Tablo 2'ye bakıldığında hem eğitim hem de test aşamasında hata yüzdelerinden MAPE çok düşük seyretmektedir. Şekil 4(i)'ye bakıldığında gerçek değerlerle tahmin değerleri test aşamasında büyük oranda örtüşürken eğitim aşamasında meydana gelen sapmadan dolayı gerçek değer ile tahmin değerleri düşük oranda örtüşmektedir.

Petrokok ile elektrik üretimi serisinde yapılan model çalışmasında 500 iterasyonluk gerçekleştirilen eğitimde 11 iterasyondan sonra değişikliğin fazla olmadığı görülmüştür. Bu sonuçlar Şekil 4(j) ve Tablo 2'de gösterilmiştir. Ayrıca $\alpha, \beta$ ve $\gamma$ değerleri sırasıyla $0.431,0.268$ ve 0.237 olarak tespit edilmiştir. Tablo 2'ye bakıldığında hem eğitim hem de test aşamasında hata yüzdelerinden MAPE çok yüksek seyretmektedir. Şekil 4(j)'ye bakıldığında gerçek değerlerle tahmin değerleri eğitim aşamasının dörtte birlik bölümünde örtüşürken diğer bölümde ve test aşamasında yüksek oranda sapmalar olmuştur. Yani doğru tahmin sonuçları verememiştir.

Petrol sıvıları ile elektrik üretimi serisinde yapılan model çalışmasında 500 iterasyonluk gerçekleştirilen eğitimde 11 iterasyondan sonra değişikliğin fazla olmadığı görülmüştür. Bu sonuçlar Şekil 4(k) ve Tablo 2'de gösterilmiştir. Ayrıca $\alpha, \beta$ ve $\gamma$ değerleri sırasıyla $0.442,0.343$ ve 0.248 olarak tespit edilmiştir. Tablo 2'ye bakıldığında hem eğitim hem de test aşamasında hata 
yüzdelerinden MAPE çok yüksek seyretmektedir. Şekil 4(k)’ya bakıldığında gerçek değerlerle tahmin değerleri eğitim aşamasının dörtte birlik bölümünde örtüşürken diğer bölümde ve test aşamasında yüksek oranda sapmalar olmuştur.

11 ayrı veri setinde çeyrek dönemde sezonsallık değerleri( $($ ) beklenildiği gibi yüksek seyretmektedir ve birbirine yakın sonuçlar vermektedir.

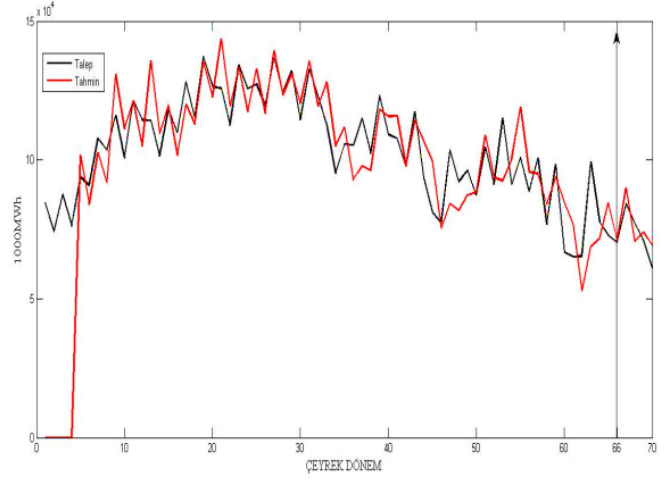

(a)

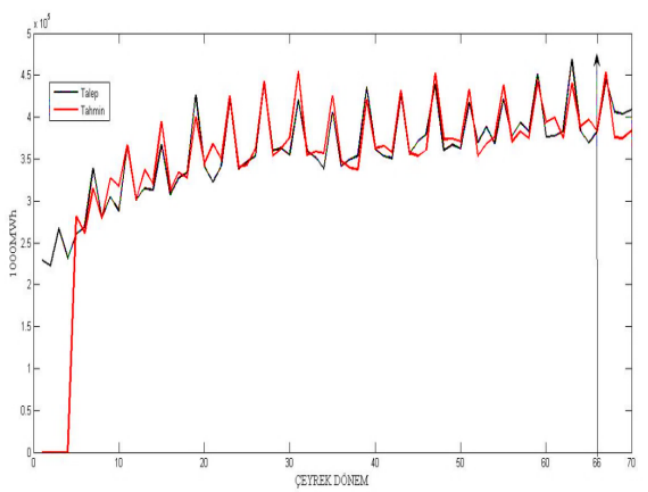

(c)

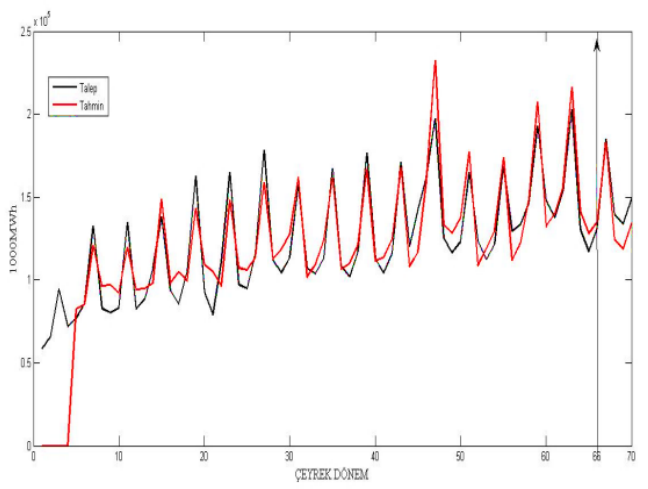

(e)

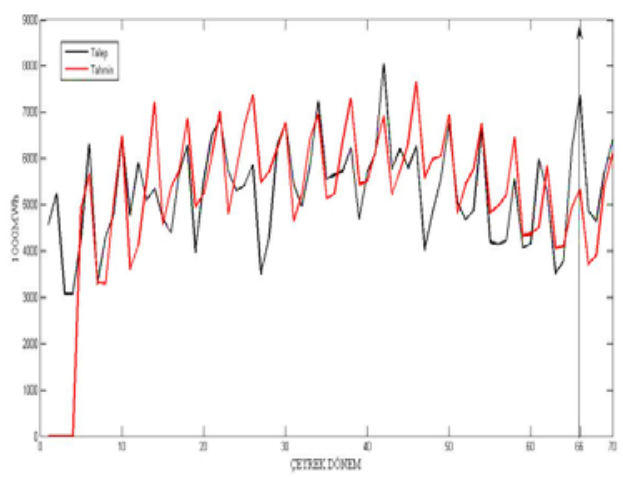

(b)

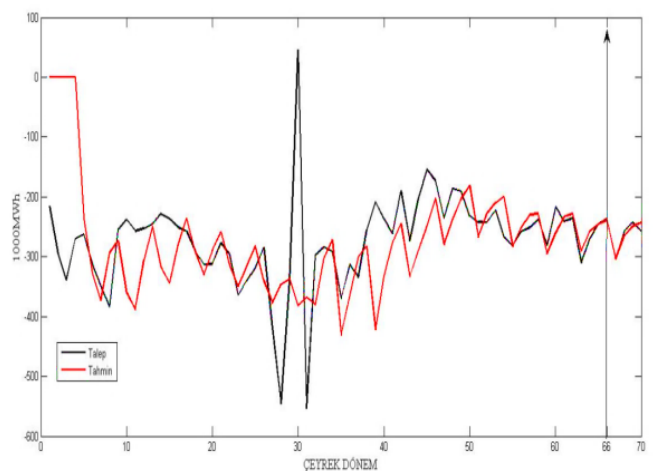

(d)

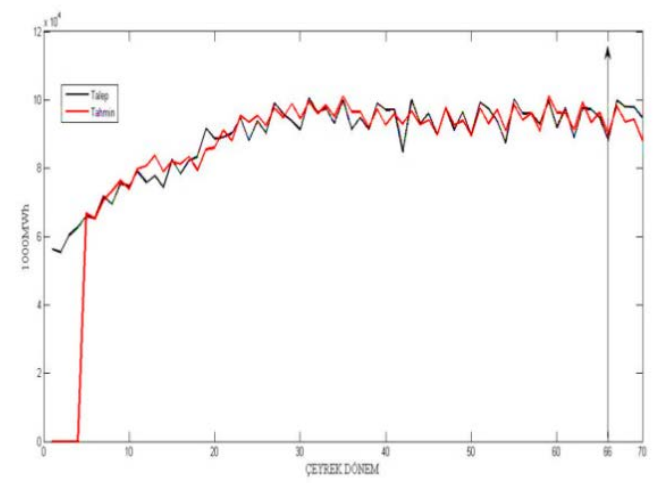

(f) 
Özger et. al

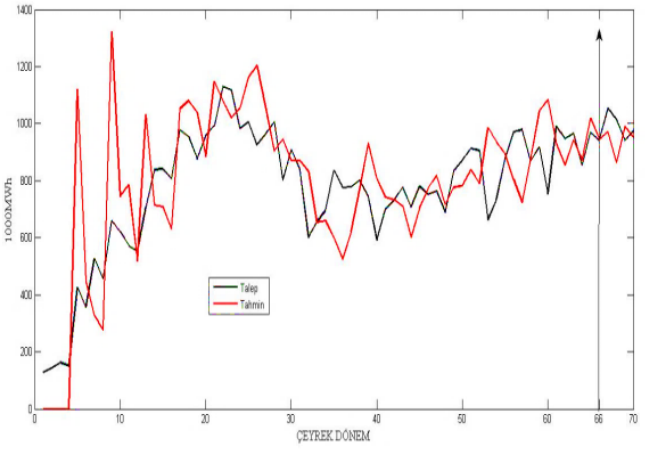

(g)

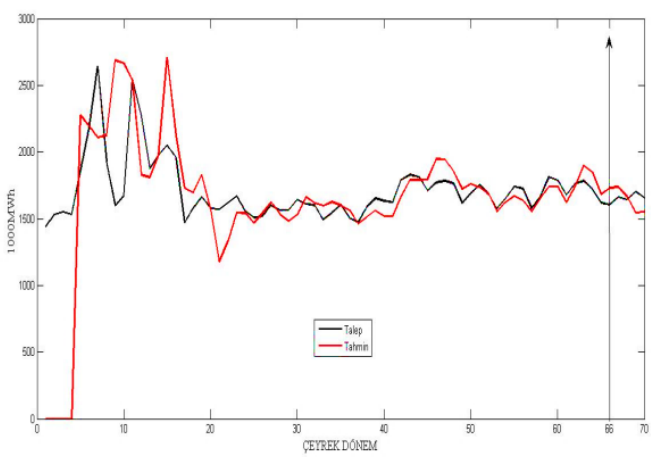

(i)

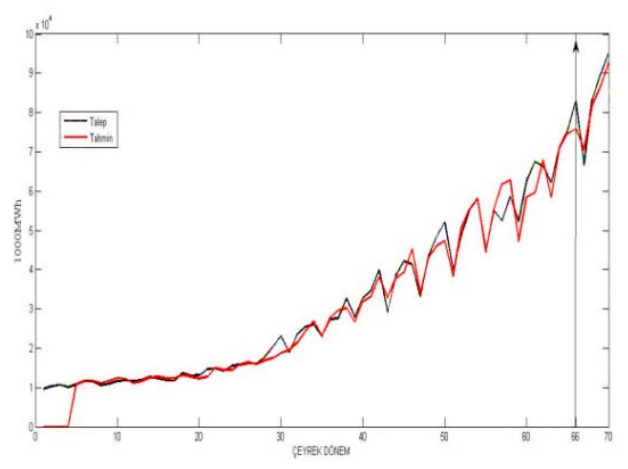

(h)

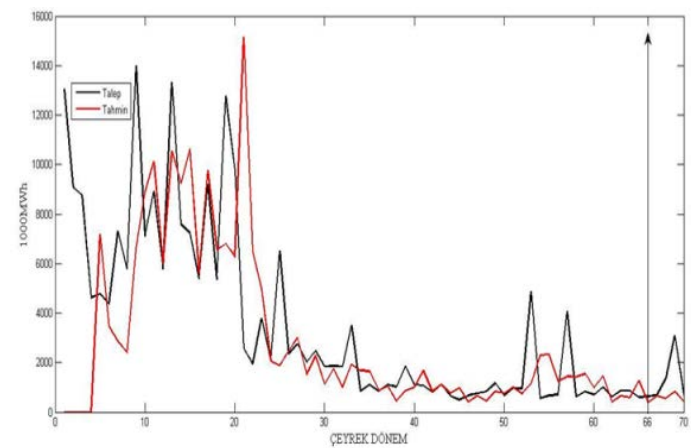

(j)

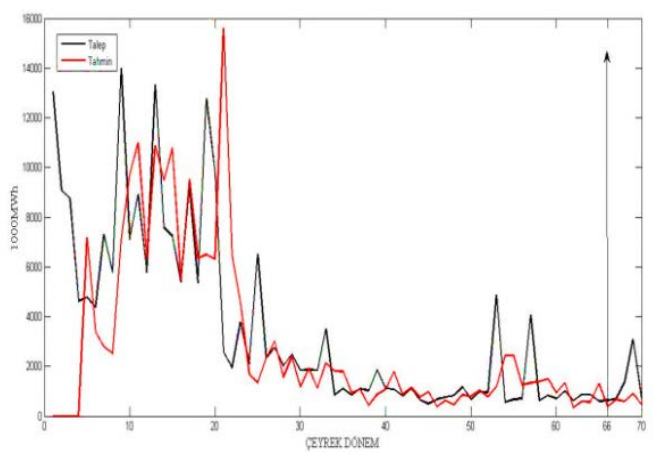

$(\mathrm{k})$

Şekil 4 Çeyrek dönemlik elektrik üretimleri ve tahmin sonuçları (a) Kömür, (b) Hidrelektrik, (c) Yakıtlar, (d) Pompaj depolamalı hidroelektrik, (e) Doğal gaz, (f) Nükleer enerji, (g) Diğer gazlar, (h) Diğer yenilenebilir enerji kaynakları, (i) Diğer kaynaklar, (j) Petrokok, (k) Petrol sıvıları.

\subsection{Yük tahmini genel değerlendirmesi}

MAPE değerleri şekilleri yorumlamamıza büyük oranda katk1 sağlamıştır. Tablo 4'e bakıldığında görüldüğ̈̈ gibi MAPE değerleri düştükçe tahmin değerlerinin gerçek değerlerle örtüşme oranı artmaktadır. Tam tersine MAPE değeri yükseldikçe tahmin değerlerinin gerçek değerlerden uzaklaştığı görülmektedir. Yani tablo incelendiğinde yukarıda bahsettiğimiz en iyi sonuçları veren nükleer enerji ve diğer yenilenebilir kaynaklar en düşük MAPE değerlerine sahiptir. Yine en kötü sonuçları veren petrokok ve petrol sıvıları en yüksek MAPE değerlerine sahiptir.

\section{Sonuç}

Holt-Winters ve Genetik Algoritma yöntemleri Matlab programında kodlanarak ikisinin birlikte çalıştığı bir program geliştirilmiştir. Geliştirilen bu program ile elektrik yük tahmini yapılmıştır. Bu 
program ile yapılan tahminlerin çoğunluğunda başarılı sonuçlar elde edilmiştir. Tahmin değerlerinin büyük oranda gerçek değerlerle örtüştüğü gözlemlenmiştir. Ayrıca yıllık tahminlerin çeyrek dönemlik tahmin değerlerine göre daha başarılı sonuçlar verdiği gözlemlenmiştir. Dolayısıyla Genetik Algoritmanın rahatlıkla HWÜD yönteminde kullanımı sağlanabilir.

Genetik Algoritmada amaç fonksiyonu olarak MAD hata kriterinin minimizasyonu kullanılmıştır. İleriye yönelik Genetik Algoritmada MAD dışında başka hata kriterleri kullanılarak bu katsayıların bulunması sağlanabilir. Bu hata kriterleri kıyaslanarak hangisinin en iyi katsayı değerlerini bulduğu tespit edilebilir. Sonraki aşamada farklı sezgisel algoritmalar ile performans testi yapılacaktır.

Tablo 211 verisetinin farklı zaman kırılımlarındaki eğitim ve test hataları

\begin{tabular}{|c|c|c|c|c|c|c|c|c|c|c|c|c|}
\hline \multirow{3}{*}{$\begin{array}{l}\overrightarrow{\bar{v}} \\
\bar{\Delta}\end{array}$} & \multicolumn{6}{|c|}{ Aylık Tahmin } & \multicolumn{6}{|c|}{ Çeyreklik Tahmin } \\
\hline & \multicolumn{3}{|c|}{ Eğitim } & \multicolumn{3}{|c|}{ Test } & \multicolumn{3}{|c|}{ Eğitim } & \multicolumn{3}{|c|}{ Test } \\
\hline & MAD & MAPE & MPE & MAD & MAPE & MPE & MAD & MAPE & MPE & MAD & MAPE & MPE \\
\hline 1 & 2101,1 & 6,630 & $-1,450$ & 2185 & 9,079 & $-0,83$ & 8325,30 & 8,439 & $-0,842$ & 5617,83 & 7,881 & $-3,802$ \\
\hline 2 & 229,35 & 13,006 & $-0,984$ & 396,8 & 20,91 & $-16,0$ & 711,363 & 13,894 & $-5,368$ & 623,378 & 12,385 & 12,385 \\
\hline 3 & 3981,7 & 3,272 & $-0,745$ & 9634,8 & 6,880 & 6,880 & 12404,34 & 3,443 & $-1,181$ & 23647,6 & 5,768 & 4,699 \\
\hline 4 & 21,275 & 24,242 & $-0,677$ & 10,582 & 13,090 & $-11,6$ & 51,145 & 31,610 & 7,072 & 7,725 & 3,017 & 0,205 \\
\hline 5 & 2710,4 & 6,693 & $-0,618$ & 8252,2 & 15,683 & 15,68 & 10445,32 & 8,764 & $-3,075$ & 11818,3 & 8,318 & 8,318 \\
\hline 6 & 899,87 & 3,093 & $-0,387$ & 1473,4 & 4,558 & 4,557 & 2296,710 & 2,597 & $-0,703$ & 4060,12 & 4,195 & 4,195 \\
\hline 7 & 50,246 & 20,714 & $-10,67$ & 42,962 & 13,200 & $-11,5$ & 134,989 & 19,197 & $-6,459$ & 76,569 & 7,588 & 5,047 \\
\hline 8 & 723,20 & 6,360 & 0,030 & 1487,6 & 5,291 & 2,360 & 1653,655 & 4,973 & 1,238 & 2728,89 & 3,405 & 0,538 \\
\hline 9 & 34,678 & 5,908 & $-1,148$ & 46,126 & 8,688 & 2,972 & 141,322 & 8,061 & $-2,455$ & 90,010 & 5,372 & 2,435 \\
\hline 10 & 436,98 & 46,334 & $-15,44$ & 368,81 & 57,654 & 48,52 & 1423,743 & 55,283 & $-20,190$ & 845,938 & 44,095 & 44,095 \\
\hline 11 & 425,72 & 43,728 & $-14,90$ & 379,82 & 57,929 & 57,65 & 1461,915 & 57,233 & $-21,830$ & 808,713 & 41,027 & 41,027 \\
\hline
\end{tabular}

\section{Referanslar}

[1] Türkiye Elektrik ve Taahhüt A.Ş.-2015 yılı Sektör-Raporu, [Online]. Available: https://docplayer.biz.tr/24289751-1-giris-turkiyede-elektrik-sektorunun-tarihsel-gelisimidunyada-elektrik-piyasasina-genel-bakis-6.html.

[2] Aksoy, M., Dünyanın Enerji Görünümü, İNSAMER, Ekim 2016.

[3] Enerji ve Tabi Kaynaklar Bakanlığı, 2018. [Online]. Available: https://www.enerji.gov.tr/trTR/Sayfalar/Elektrik.

[4] A.C. Toker, O. Korkmaz, "Türkiye Kısa Süreli Elektrik Talebinin Saatlik Olarak Tahmin Edilmesi,” II. Elektrik Tesisat Ulusal Kongresi Bildirileri, Uluslar Arası Fuar Alanı, İzmir, 2427, Kasim, 2011.

[5] M. Özcan and M. Yıldırım, "The Impact of Capital Subsidy Incentive on Renewable Energy Deployment in Long-Term Power Generation Expansion Planning," Sakarya University Journal of Computer and Information Sciences, 1:3 (2018) 1-19.

[6] Seker, S.E., Zaman Serisi Analizi (Time Series Analysis). YBS Ansiklopedi, Cilt 2, Sayı 4, Aralık, 2015.

[7] Bozüyük, T., Gökçe, İ., Yağc1, C., Akar, G., Yapay Zeka Tekniklerinin Endüstrideki Uygulamaları. Marmara Üniversitesi Teknik Bilimler Meslek Yüksek Okulu Elektrik Programı, İstanbul, 2005.

[8] Çunkaş, M., Genetik Algoritmalar ve Uygulamaları. Selçuk Üniversitesi Teknik Eğitim Fakültesi, Elektronik-Bilgisayar Eğitimi, Ders Notları, Bahar, 2006. 
[9] Tonta, Y., Regresyon Analizi. Hacettepe Üniversitesi, BBY, 2008.

[10] Boltürk, E., Elektrik Talep Tahmininde Kullanılan Yöntemlerin Karşılaştırılması, Yüksek Lisans Tezi, İstanbul Teknik Üniversitesi, İstanbul, 2013.

[11] Dünyada Enerji Sorunu, Haziran 12, $2018 . \quad$ [Online]. Available: http://ekonometri.com.tr/blog/dunya-enerji-sorunu.

[12] Yiğit, V., Genetik Algoritma ile Türkiye Net Elektrik Enerjisi Tüketiminin 2020, Yılına Kadar Tahmini, International Journal of Engineering Research and Development, Vol.3, No.2, June 2011.

[13] Yavuzdemir, M., Türkiye'nin Kısa Dönem Yıllık Brüt Elektrik Enerjisi Talep Tahmini, Yüksek Lisans Tezi, Ankara Üniversitesi, Ankara, 2014.

[14] Başoğlu, B., Bulut, M., Kısa dönem elektrik talep tahminleri için yapay sinir ağları ve uzman sistemler tabanlı hibrit sistem geliştirilmesi, Journal of the Faculty of Engineering and Architecture of Gazi University 32:2 (2017) 575-583.

[15] Altınay, G., Aylık Elektrik Talebinin Mevsimsel Model ile Orta Dönem Öngörüsü, Enerji, Piyasa ve Düzenleme, Cilt:1, Sayı:1, 2010, Sayfa:1-23.

[16] M. Akpinar and N. Yumusak, "Year Ahead Demand Forecast of City Natural Gas Using Seasonal Time Series Methods,” Energies, vol. 9, no. 9, p. 727, Sep. 2016.

[17] Soysal, M., Ömürgönülşen, M., Türk Turizm Sektöründe Talep Tahmini Üzerine Bir Uygulama, Anatolia: Turizm Araştırmaları Dergisi, Cilt 21, Sayı 1, Bahar: 128-136, 2010.

[18] Çuhadar, M., Muğla İline Yönelik Dış Turizm Talebinin Modellenmesi ve 2012-2013 Yılları için Tahminlenmesi, Internati onal Journal of Economic and Administrati ve Studies, Year:6 Number 12, Winter 2014 ISSN 1307-9832.

[19] Irmak, S., Köksal, C.D., Asilkan, Ö., Hastanelerin Gelecekteki Hasta Yoğunluklarının Veri Madenciliği Yöntemleri İle Tahmin Edilmesi, Uluslararası Alanya İşletme Fakültesi Dergisi, Y11:2012, C:4, S:1, s.101-114.

[20] Demir, İ., Genç, T., Karaboğa, H.A., Türkiye Cumhuriyeti Merkez Bankası Altın Rezervinin Holt-Winters Üstel Düzleme Yöntemi ve Yapay Sinir Ağları ile İncelenmesi, Uluslararas1 Ekonomi, İşletme ve Politika Dergisi, 2018, 2(1), 131-146.

[21] Çoban, O., Özcan, C.C., Sektörel Açıdan Enerjinin Artan Önemi: Konya İli için Bir Doğalgaz Talep Tahmini Denemesi, Sosyal Ekonomik Araştırmalar Dergisi 11(22), 85-106, 2011.

[22] Aydın, M.Ç., Giyim Endüstrisinde Talep Tahmin Yöntemlerinin Uygulanması: Örnek Bir Uygulama, Yüksek Lisans Tezi, Selçuk Üniversitesi, Konya, 2017.

[23] Ündemir, Y.G., Sosyal Güvenliğin Önemli Değişkenlerinin Zaman Serileri Analizi ile Öngörüsü, Sosyal Güvenlik Uzmanlık Tezi, Sosyal Güvenlik Kurumu Başkanlığı, Ankara, 2009.

[24] Razali S., Rusinam, M.S., Zawawi, N.I., Arbin, N., Forecasting of Water Consumptions Expenditure Using Holt-Winters and ARIMA, IOP Conf. Series, Journal of Physics, Conf. Series 995 (2018)-012041. 
[25] Tikunov, D., Nishimura, T., Traffic Prediction for Mobile Network Using Holt-Winters Exponential Smoothing, 15th International Conference on Software, Telecommunications and Computer Networks, 2017.

[26] Valakevicius, E., Brazenas, M., Application of the Seasonal Holt-Winters Model to Study Exchange Rate Volatility, Inzinerine Ekonomika-Engineering Economics, 2015, 26(4), 384390.

[27] Pulat, M., Kocakoç, İ.D., Gezgin Satıcı Probleminin Genetik Algoritmalar Kullanarak Çözümünde Çaprazlama Operatörlerinin Örnek Olaylar Bazlı İncelenmesi, Yöneylem Araştırmas1 endüstri Mühendisliği 36. Kongresi, Bornova, Temmuz, 2016.

[28] Sümer, E., Türker, M., Yüksek Çözünürlüklü Uydu Görüntülerinden Genetik Algoritma Yaklaşımı Kullanılarak Kentsel Binaların Tespiti, Türkiye Ulusal Fotogrametri ve Uzaktan Algılama Birliği VII. Teknik Sempozyumu (TUFUAB), Trabzon, 23-24 Mayıs, 2013.

[29] Pakkan, B., Ermiş, M., İnsansız Hava Araçlarının Genetik Algoritma Yöntemiyle Çoklu Hedeflere Planlamas1, Havac1lık ve Uzay Teknolojileri Dergisi, Ocak, 2010, Cilt:4, Sayı:3, (7784).

[30] Coşkun, N., Acil Servis Sistemlerinde Yerleşim Problemine Analitik ve Genetik Programlama Yaklaşımları, Yüksek Lisans Tezi, Çukurova Üniversitesi, Adana, 2007.

[31] Dündar S., Demiryolu Trafik Kontrolü Probleminin Genetik Algoritmalarla Çözümü, Doktora Tezi, Yıldız Teknik Üniversitesi, İstanbul, 2009.

[32] Akpinar M., Application of Genetic Algorithm for Optimization of Heat-Transfer Parameters, Sakarya University Journal of Science, 2019, 23(6), doi: https://doi.org/10.16984/saufenbilder.500643.

[33] Azmi, Nur İntan Liyana Mohd, Parameters Estimation of Holt-Winters Smoothing Method Using Genetic Algorithm, A dissertation submitted in partial fulfilment of the requirements for the award of the degree of Master of Science (Mathematics), Universiti Teknologi Malaysia, 2013.

[34] De Lurgio, S.A., Forecasting Principles and Applications, Irwin/Mc Graw-Hill, Boston, 1998.

[35] Çetin, E., Yapay Zeka Uygulamaları, Seçkin Yayıncılık, Sayfa 379-420, Ankara, 2016.

[36] Melanie, M., An Introduction to Genetic Algorithms, 5th ed. London: MIT Press, 1999.

[37] Haupt, R. L., Haupt, S. E., Practical Genetic Algorithms, 2nd ed. New York, NY, USA: Wiley, 2004. 